\title{
STUDI KADAR KOLESTEROL TOTAL PADA AKSEPTOR PIL KELUARGA BERENCANA (KB)
}

\author{
Nurul Ni’ma Azis ${ }^{1)}$, Hasnah $^{1)}$, Cia Munifa ${ }^{1)}$ \\ 1) Prodi D3 Teknologi Laboratorium Medis Politeknik Kesehatan Muhammadiyah Makassar \\ E-mail:enenima03@gmail.com
}

\begin{abstract}
Abstrak
Alat kontrasepsi oral adalah salah alat kontrasepsi yang umumnya dipakai masyarakat untuk mencegah kehamilan. Ada 2 macam kontrasepsi yaitu kontrasepsi hormonal dan non hormonal kontrasepsi hormonal salah satunya yaitu pil KB . Kontrasepsi pil merupakan alat kontrasepsi hormonal yang berupa obat dalam bentuk pil yang dimasukan melalui mulut (oral), yang mengandung estrogen dan proestrogen, bertujuan untuk mencegah ovulasi (pematangan dan pelepasan sel telur). Tujuan penelitian ini untuk mengukur kadar kolesterol pada wanita akseptor pil KB. Tujuan penelitian ini untuk mengetahui kadar kolesterol total pada akseptor pil KB. Jenis penelitian ini bersifat observasi laboratorium dengan jumlah sampel sebanyak 20 orang dengan pengambilan sampel dilakukan secara purposive sampling dengan kriteria penggunaan selama 1.5 tahun. Berdasarkan hasil penelitian yang diperoleh sebanyak 3 (15\%) sampel mengalami kenaikan kadar kolesterol total dan 17 (85\%) sampel tidak mengalami kenaikan kadar kolesterol total.
\end{abstract}

Kata Kunci : Pil KB, Akseptor pil KB, Kolesterol Total

\section{PENDAHULUAN}

Program Keluarga Berencana (KB) merupakan program yang dicanangkan pemerintah dengan tujuan mewujudkan keluarga kecil bahagia, sejahtera yang menjadi dasar bagi terwujudnya masyarakat yang sejahtera melalui pengendalian kelahiran dan pertumbuhan penduduk di Indonesia.

Salah satu alat kontrasepsi yang digunakan untuk mencegah kehamilan yaitu Pil KB yang merupakan jenis alat kontrasepsi oral yang mengandung hormon estrogen atau hormon progesteron maupun kombinasi keduanya. Pil KB mengandung etinil estradiol $30 \mathrm{mcg}$ dan $150 \mathrm{mcg}$ levonorgestrel (Sartono, 2005). Kontrasepsi hormonal dapat mempengaruhi tekanan darah baik estrogen maupun progesteron, dimana hormon esterogen ini dapat meningkatkan retensi elektrolit dalam ginjal sehingga terjadi peningkatan reabsorbsi natrium dan air yang menyebabkan hipervolemi sementara hormon progesteron dapat menurunkan kadar HDL - kolesterol serta meningkatkan LDL - kolesterol sehingga dapat terjadi aterosklerosis dan resiko penyakit kardiovaskuler (Rohmatin.N, 2015).

Penyakit kardiovaskular adalah penyebab utama kematian wanita dan pria di beberapa negara di seluruh dunia yang menyebabkan hampir 500.000 wanita meninggal setiap tahun, termasuk lebih dari 250.000 setiap tahunnya akibat arteri koroner (kevin et al, 2014). Berdasarkan fakta yang ada para pengguna pil KB mengalami kenaikan Berat Badan (BB) setelah menggunakan pil KB (Eckholm EP, 1985).

Berdasarkan data yang di ambil dari dari salah satu sumber Badan Kependudukan dan Keluarga Berencana Nasional (BKKBN) Kabupaten Tojo UnaUna khususnya di kecamatan Ampana Tete penggunaan pil Keluarga Berencana (KB) oleh masyarakat yaitu sekitar 30\%. Ini berarti alat kontrasepsi oral, merupakan salah satu alat kontrasepsi yang banyak digunakan oleh para peserta Keluarga Berencana (KB). Berdasarkan hal tersebut, sebagian masyarakat yang ada di kecamatan Ampana Tete menggunakan pil kombinasi 1 jenis untuk 
1 siklus dengan dosis rendah yang diberikan dari Badan Kependudukan dan Keluarga Berencana Nasional (BKKBN) Kabupaten Tojo Una-Una yang terdiri dari 28 tablet. Tiap tablet mengandung etinil estradiol $30 \mathrm{mcg}$ dan $150 \mathrm{mcg}$ levonorgestrel yang dapat mengganggu metabolisme lipid (lemak) (Sartono, 2005).

\section{METODE PENELITIAN}

\section{Alat dan Bahan}

Alat yang digunakan berupa fotometerautomaticMindray BS-200, Mikropipet, Tip, tabung vakum, torniquet, needle, holder, plester, Kapas alkohol $70 \%$, Serum dan Reagen Kolesterol.

\section{Prosedur Kerja}

Siapkan serum pasien kemudian dipipet sebanyak 10 mikron lalu masukkan ke dalam tabung sampel. Selanjutnya dipipet reagen kerja kolesterol lalu masukkan dalam tabung yang telah terisi dengan serum. Hogenkan lalu diinkubasi selama 5 menit pada suhu $37^{0}$ C. Lalu absorbance sampel diukur menggunakan fotometer automatic Mindray BS-200. Nilai normal kadar kolesterol sebanyak $<200 \mathrm{mg} / \mathrm{dl}$.

\section{Analisis Data}

Analisis data disajikan dalam bentuk tabel untuk kadar kolesterol akseptor pil $\mathrm{KB}$ dan dilakukan analisa secara narasi deskriptif.

\section{HASIL PENELITIAN}

Berdasarkan hasil penelitian kadar kolesterol akseptor pil KB berdasarkan lama penggunaan diperoleh hasil pada table 1 berikut:

\begin{tabular}{ccc} 
Tabel 1. & $\begin{array}{c}\text { Kadar Kolesterol } \\
\text { berdasarkan } \\
\text { Penggunaan }\end{array}$ & $\begin{array}{c}\text { Total } \\
\text { Lama }\end{array}$ \\
\hline $\begin{array}{c}\text { Kode } \\
\text { Sampel }\end{array}$ & $\begin{array}{c}\text { Lama } \\
\text { Penggunaan } \\
\text { Pil } \\
\text { (Tahun) }\end{array}$ & $\begin{array}{c}\text { Kadar } \\
\text { Kolesterol } \\
(\mathbf{m g} / \mathbf{d l})\end{array}$ \\
\hline A & 6 & 243 \\
B & 1 & 161 \\
C & 1 & 152 \\
D & 4 & 167 \\
E & 8 & 199 \\
\hline
\end{tabular}

\begin{tabular}{ccc}
\hline $\mathrm{F}$ & 1,8 & 147 \\
$\mathrm{G}$ & 1,1 & 199 \\
$\mathrm{H}$ & 1,3 & 166 \\
$\mathrm{I}$ & 3 & 175 \\
$\mathrm{~J}$ & 1 & 116 \\
$\mathrm{~K}$ & 6 & 153 \\
$\mathrm{~L}$ & 6 & 156 \\
$\mathrm{M}$ & 1 & 151 \\
$\mathrm{~N}$ & 3 & 211 \\
$\mathrm{O}$ & 12 & 169 \\
$\mathrm{P}$ & 1,5 & 186 \\
$\mathrm{Q}$ & 1 & 138 \\
$\mathrm{R}$ & 6 & 230 \\
$\mathrm{~S}$ & 3 & 181 \\
$\mathrm{~T}$ & 8 & 159 \\
\hline
\end{tabular}

Tabel 2. Persentasi Kolesterol Total Akseptor Pil KB

\begin{tabular}{lll}
\hline $\begin{array}{c}\text { Kolesterol } \\
\text { Total }\end{array}$ & Sampel & $\begin{array}{c}\text { Presentasi } \\
(\boldsymbol{\%})\end{array}$ \\
\hline Normal & 17 & $15 \%$ \\
Tinggi (High) & 3 & $85 \%$ \\
\hline
\end{tabular}

\section{PEMBAHASAN}

Penelitian ini di lakukan secara observasi laboratorium, penelitian ini bertujuan untuk mengetahui gambaran kadar kolesterol total pada akseptor pil KB minimal 1.5 tahun. Spesimen yang digunakan adalah serum dari akseptor pil $\mathrm{KB}$ yang diperiksa dengan menggunakan Mindray BS-200 dengan metode CHODPAP dengan prinsip pemeriksaan oksidasi enzimatik (dengan adanya phenol peroksidase) dapat ditentukan cholesterol yang berdasarkan terbentuknya quinoneimine sebagai hasil reaksi antara $\mathrm{H}_{2} \mathrm{O}_{2}$ dengan 4-aminophenazone. Berdasarkan penelitian dari 20 sampel di peroleh $3(15 \%)$ sampel memiliki kadar kolesterol total meningkat dan Sebanyak $17(85 \%)$ memiliki kadar kolesterol total darah adalah normal.

Pada sampel yang diperiksa dengan kode sampel A, serum tersebut lipemik, serum lipemik merupakan serum yang keruh, berwarna putih seperti susu, biasanya diakibatkan adanya dislipidemia (peningkatan kadar lemak dalam darah) atau adanya kontaminasi bakteri. 
Makanan yang baru dikonsumsi, terutama yang mengandung lemak dapat menyebabkan lipidemia (peningkatan kadar lemak darah untuk sementara) (Penuntun Praktikum Kimia Klinik II).

Pola hidup modern dapat memicu kolesterol meningkat karena aktivitas sehari-hari yang menyita waktu, mengabaikan olahraga dan yang mengkonsumsi makanan yang serba praktis dan mengandung kolesterol tinggi (Kusmiati dan Pratiwi, 2015).

Konsumsi makanan yang tinggi lemak dan kolesterol akan meningkatkan kadar kolesterol darah sehingga hati mempunyai cukup ladar kolesterol dan akan menghentikan pengambilan LDL yang dapat meningkatkan kadar kolesterol. Kadar LDL yang tinggi akan menyebabkan kolesterol lebih banyak melekat pada dinding-dinding pembuluh darah. Kolesterol yang melekat itu berlahan-lahan akan mudah membentuk tumpukan-tumpukan yang mengendap, seperti plak-plak pada dinding pembuluh darah. Proses penyumbatan ini kemudian dikenal sebagai aterosklerosis yang terjadi pada pembuluh darah inilah kemudian berlanjut menjadi PJK.

Faktor yang mempengaruhi kadar kolesterol selain pola makan tinggi lemak juga dipengaruhi aktivitas fisik. Aktivitas fisik yang hanya duduk terus menerus dalam bekerja (sedentary) dan kurang gerak dapat meningkatkan resiko PJK. Aktivitas teratur akan meningkatkan aktivitas enzim lipoprotein lipase (LPL) dan menurukan aktivitas enzim hepatic lipase. lipoprotein lipase membantu memindahkan LDL dan kadar kolesterol menurun (Kurniawati.F, 2015).

Kadar kolesterol meningkat dengan bertambahnya usia, Karena pada usia lanjut badan semakin lama maka semakin malas digerakkan, faktor tersebut yang dapat menyebabkan pembuluh darah menyempit sehingga akan menimbulkan penyakit seperti jantung koroner, stroke, hipertensi dan lain-lain (Kusmiati dan Pratiwi). Jika kaum wanita sudah mendekati umur 40 tahun, mereka sebaiknya jangan lagi menggunakan pil untuk mencegah kehamilan berdasarkan pertimbangan dari sekian penemuan kerdokteran. Korelasi antara penggunaan pil di negara-negara maju dengan semakin tingginya resiko penyakit kardiovaskular seperti serangan jantung serta penghambatan pada pembuluh darah (Eckhlom.P, 1985)

\section{DAFTAR PUSTAKA}

Adib, M. 2009.Cara Mudah Memahami Dan Menghindari Hipertensi Jantung Dan Stroke. Yogyakarta, Dianloka Pustaka

Arianda Dedy. 2015. Buku Saku Analis Kesehatan revisi ke-5. Bekasi, AnalisMuslimPublishing.

Baraas Faisal. 1994. Mencegah Serangan Jantung Dengan Menekan Kolesterol. Jakarta, Gramedia Pustaka Utama

Bariyyah Khairul. 2015. Gambaran Hasil Pemeriksaan Kolesterol Pada Akseptor Keluarga Berencana (Kb) Suntik Di Puskesmas Minasa Upa. Karya Tulis Ilmiah Tidak Diterbitkan. Makassar, Program Diploma III Akademi Analis Kesehatan Muhammadiyah Makassar.

Eckholm, P Erik.1985. Masalah Kesehatan. Jakarta, Pt Gramedia

Gray H.Hoon, Et Al. 2003. Lecture Notes Kardiologi. Edisi Ke Empat. Jakarta, Erlangga

Institut Pertanian Bogor. 2001. Pangan Dan Gizi. Bogor, Sagung Seto

Kee Lefever Joyce.1997. Pemeriksaan Laboratorium Dan Diagonistik. Jakarta , Buku Kedokteran Ecg.

Kevin A Et Al, 2014. Penyakit Kardiovaskular Pada Wanita. Jakarta, Erlangga

Kurniawati.F, 2015. Hubungan Konsumsi Lemak Dan Aktivitas Fisik Dengan Kadar Kolesterol Darah Dan Kadar Low Density Lipoprotein Pada Pasien 
Penyakit Jantung Koroner Rawat Jalan Di Rumah Sakit Umum Daerah dr. Moewardi . Skripsi Tidak Diterbitkan. Surakarta, Universitas Muhammadiyah Surakarta.

Kusmiati Meti Dan Pratiwi Dini. 2015.Gambaran Profil Lipid Pada Pasien Yang Mengalami Hipertensi Di Desa Setiajaya Kota Tasikmalaya. Jurnal Kesehatan Bakti Tunas Husada Vol 13 No 1. Tasikmalaya, Stikes Bakti Tunas Husada Tasikmalaya. Larasati, K. 2015. Gambaran Hasil Pemeriksaan Kadar Hemoglobin Pada Perokok Aktif Di Wilayah Samata Kecamatan Sombaopu Kabupaten Gowa. Karya Tulis Ilmiah Tidak Diterbitkan. Makassar, Program Studi DIII Analis Kesehatan Sekolah Tinggi Ilmu Kesehatan Mega Rezky Makassar.
Muchtadi Deddy Et Al. 1993. Metabolisme Zat Gizi 1. Jakarta, Pustaka Sinar Harapan

Norwitz Errol \& Schorge John. 2007. Et A Glance Obstetri \& Ginekologi. Jakarta, Erlangga

Rohmatin Naila, 2015. Hubungan Antara Umur Dan Lama Penggunaan Terhadap Keluhan Kesehatan Pada Wanita Usia Subur Pengguna Alat Kontrasepsi Hormonal Dan Non-Hormonal Di Pulau Jawa Tahun 2012. Skripsi Tidak Diterbitkan. Jakarta, Universitas Islam Negeri Syarif Hidayatullah Jakarta

Sartono. 2005. Obat Dan Wanita. Bandung, Penerbit ITB

Uliyah Mar'atul. 2010. Awas Kb, Panduan Aman Dan Sehat Memilih Alat KB. Yogyakarta, PT Pustaka Insan Madani

Umar, Bakri. 2015. Penuntun Praktik Klinik Laboratorium Kesehatan. Makassar. 